\title{
THE INTERRELATION BETWEEN ECONOMIC GROWTH AND NATIONAL ECONOMIC COMPETITIVENESS: THE CASE OF UKRAINE
}

\author{
- Halyna Fyliuk, Ihor Honchar, Vasylyna Kolosha
}

\begin{abstract}
Globalization causes large-scale changes in technological, economic, political and social fields of social development. These changes have a contradictory impact on the development of national economies and their competitiveness. Ceteris paribus, there is a tight interrelation between country's economic competitiveness and a rate of its economic growth: the higher the rates of economic growth in the country, the bigger chance for growth in its national competitiveness and vice versa. Various indicators can be used characterize and estimate a country's competitiveness, with parameters featured in the Global Competitiveness Index (GCI) playing a special role. This index is to some extent abstract, and provides only general idea about the type competitiveness formation of a country. It does not allow estimations regarding trends in economic development, as it aggregates 114 indicators which have multidirectional impacts. The key characteristic of national economic competitiveness is a particular country's ability to achieve steady high growth rates (World Economic Forum). For this reason, we suppose that the one of the main indicators of competitiveness level is GDP per capita, a factor reflects consumption volumes per capita and is highly correlated with the welfare level in the country. The purpose of this research is a comparative analysis of the competitiveness of the Ukrainian economy along with the population's standard of living with that of other countries, along with the reasoning for the assumption that economic growth rates are necessary for Ukraine to achieve the competitiveness level of other developed countries. We argue that Ukraine and other countries with an average income of 8000-9000 US dollars GDP per capita (PPP) annually should ensure an annual relative growth acceleration of at least $8 \%$ to achieve the level of economic development of more highly developed countries.
\end{abstract}

Keywords: economic growth, national economic competitiveness, GDP per capita, purchasing power parity JEL Classification: O47, O57, P46, P52.

Received: February, 2019

1st Revision: May, 2019

Accepted: June, 2019

\section{INTRODUCTION}

The active incorporation of revolutionary new technologies along with the transformation of the current system of international relations characterize the formation of the global informa- 
tion society at the beginning of the 21st century. Large-scale changes taking place in technological, economic, political and social fields have recently led to an unprecedented escalation of intercountry competition for access to new progressive knowledge, innovative technologies, limited natural and human resources, as well as for the establishment of the most favorable macroeconomic conditions for macroeconomic development within each region and each individual country. Such unprecedented changes bring on problems related to national competitiveness in the global economic environment and each country's geopolitical survival. The consequence of this situation is not only an escalation of the technological gap between progressive and regressive countries, but also a perpetual series of variations of developed countries in the ranks of the renowned global economic ratings, which are determined directly or indirectly by the level of global competitiveness achieved. For instance, in the international ranking Global Competitiveness Report, Japan moved from the 21st position in 2001 to 9th in 2017, unlike Canada, which moved from the 3 rd to 14 th position during this period. This volatility in the rankings forces countries to permanently generate new forms of competition, methods and instruments in an attempt to gain an advantage in the global economic environment, or at the very least to secure the position they have already achieved.

Ukraine has traditionally held a relatively very low position in global competitiveness rankings, and unfortunately the situation does not seem to be improving. This is caused by that fact that Ukraine does not efficiently use its economic, production and human potential. If this line of reasoning is followed, it then becomes necessary to put forth and analyze detailed explanations regarding the country's low position in the global rankings, to define the dynamics involved as well as the types of changes required, and, finally, to estimate the required rate of economic grow th necessary to improve national competitiveness.

\section{THEORETICAL BACKGROUND}

We formed a relevant theoretical basis for our analysis using theoretical preconditions stated in the publications of M. Porter, E. Reinert and J. Sachs, along with other research which in various ways focuses on issues related to intercountry comparative studies.

The problem of ensuring the competitiveness of a national economy has been studied considerably in terms of world economic theory and practice for nearly three decades now by well-known practitioners such as Botrić \& Broz (2016), Bris (2014), Olczyk (2016), Porter (1993), Reinert (2007), Sachs (2000), Sachs \& Larrain (1993). Therefore, a significant theoretical basis has been established regarding the determination of key aspects of competitiveness, instrumental factors, indicators of evaluation, etc.

The concept of national economic competitiveness has been interpreted in many ways (Bhawsar \& Chattopadhyay, 2015). Many researchers delineate it as a relative and multidimensional concept (Spence \& Hazard, 1988; Flanagan et al., 2007), a view which is generally considered synonymous with the success and economic strength in the global environment (Srivastava et al., 2006). Nevertheless, all the definitions suggested by world economic science and authoritative international organizations can be classified into two approaches according to the intended extent of the essential meaning of this term, i.e. narrow (the ability of a country to produce goods 
and services which could survive in foreign competition under conditions of the open market), and broad (an ability to manage competencies to reach long-run growth and to increase welfare). It really does not matter which definitions are used in our own assessments, as we take for granted that competitiveness ensures a country's economic growth and the prosperity of nation.

In further explanation of our position, we agree that the narrow interpretation of international competitiveness as an ability to successfully compete with rivals at the level of international markets is correct only if we apply this concept to microeconomic level. While companies compete with each other for resources and market shares, and in the case of failure some firms will exit the market, national economies themselves do not compete for resources, which are usually fixed in time and space, i.e. they never go bankrupt in an economic sense (Olczyk, 2016).

Nevertheless, we generally stick to the broad interpretation of the national competitiveness in this article. American economist J. Sachs considers competitiveness as a precondition and an instrument of country's sustainable development. He supposes that the competitiveness of a national economy depends on availability of an efficient market, production factors and other characteristics which develop the potential for achieving sustainable economic growth. A "healthy" economy should be supported by growth in business activities, governed by law and stable markets (Sachs \& Larrain, 1993). Norwegian economist E. Reinert determines competitiveness as a process that makes people and countries richer by increasing real wages and profits (Reinert, 2007).

M. Porter has emphasized the necessity to ensure a high level of national economic competitiveness as a way to increase economic welfare. He notes that competitiveness is not an end in itself. "The major target of the country," he writes, "is to ensure to its citizens a sufficiently high and growing standard of living. The capacity of a country to do this depends not on some amorphous concept of 'competitiveness' but on the level of efficient usage of such national resources as labor and capital" (Porter, 1993). Almost the same definition of national economic competitiveness is given by Dobrovic et al. (2018). These scientists interpret this term as indicating the ability to endure in the international environment and ensure the higher living standards for the population (Dobrovic et al., 2018).

A. Bris, Director of the IMD World Competitiveness Center, emphasizes in particular that no nation in the world has succeeded in developing without preserving the conditions for prosperity of the population. Based on years of research, Bris concludes that "competitiveness is a way towards progress that does not result in winners and losers," but vice versa - when two countries compete - both win (Bris, 2014).

\section{RESEARCH OBJECTIVE, METHODOLOGY AND DATA}

The purpose of this paper is to conduct a comparative analysis of trends in the development of competitiveness of the Ukrainian economy as compared to other countries worldwide, i.e. to determine the factors which restrain its improvement and to develop recommendations towards solutions to this problem. 
For our research we used:

(1) data from the International Monetary Fund for 1992-2016 regarding the economic development of 191 countries based on GDP per capita (PPP). Data until 2000 were not available for some countries because of worldwide political processes. For this reason, the algorithms for calculating statistical indicators were adjusted according to the number of countries with available data

(2) data from analytical reports evaluating results from the Global Competitiveness Index since 2006 which were published at the web-site of the World Economic Forum

(3) data about the structure of the Ukrainian economy and its foreign trade published by State Statistic Service of Ukraine

Strategic stages of the research are:

(1) worldwide characteristics of countries' economic development based on GDP per capita (PPP). For this purpose, we used methods of country's descriptive statistics to rank countries and divide them into groups. We made division into quartiles that allowed us to get 3 groups of countries: poor (1st quartile), average level of development (2nd quartile, median) and developed (3rd quartile). We estimated the economic growth rate for each group;

(2) a separate analysis of the Ukrainian economy on a current world map. We estimated positions of Ukraine in the global economy based on the annual ratings. To estimate effectiveness of economic policy in post-Soviet countries, we also compared a current level of economic development with the year of dissolution of Soviet Union when the biggest economic partners of Ukraine started to develop their own economic policy;

(3) an analysis of the reasons of significant structural changes in the Ukrainian economy. To find out these reasons, we analyzed the structure of formation of gross value added in the Ukrainian economy, estimated structural changes, policy toward innovation activity in the country and changes in foreign trade. The obtained analytical conclusions allowed to characterize a current model of the Ukrainian economy development and to expose its weaknesses;

(4) based on the current trends in the development of world economies, we have built statistical functions which allowed to evaluate GDP per capita (PPP) growth rate considering characteristics of each group of countries. The statistical forecasts of GDP per capita (PPP) growth rate for each group of countries were made based on the data of trend equations. This allowed to evaluate further perspectives of each group of countries and thus their position in the global economy;

(5) special attention was paid to the growth of Ukrainian economy, possible measures of acceleration of its economy growth. Simulation models were built to determine an optimal acceleration rate. Based on these models, we have determined minimal acceleration growth rates for Ukrainian economy to catch up the average growth rates of world economies and developed countries:

(6) the prospects of economic development of Eastern European and Baltic countries were analyzed. The trend models for economic growth of these countries were built for this purpose. According to the results of time series modelling we can conclude that Ukraine will not be able to get leading positions in the Eastern Europe even in case of successful implementation of measures of its economic growth acceleration. 


\section{RESULTS AND DISCUSSION}

The world practice suggested many indicators, which directly or indirectly assessing the level of country's competitiveness (e.g. the European Competitiveness Index, the World Knowledge Competitiveness Index, the United Kingdom Competitiveness Index, etc. (Simionescu, 2016)). In our opinion Global Competitiveness Index (GCI) is one of the most generalizing and most used ratings in the worldwide practice. It is annually published in the World Economic Forum reports (Davos). The Global Competitiveness Index integrates the macroeconomic and the micro/business aspects of competitiveness into a single index. Despite the critics related to its "analytical, methodological and quantitative problems" (Lall, 2001), we believe that this index is the most authoritative and comprehensive indicator which assesses not only the degree of national economic competitiveness, but also gives an accurate picture of its growth potential.

Unfortunately, Ukraine was not able to significantly increase the level of its competitiveness after proclaiming independence. The rank of Ukraine in the GCI rating (Figure 1) shows this. The score of GCI for Ukraine varied around 4 during different years. That fact indicates the lack of real progress.

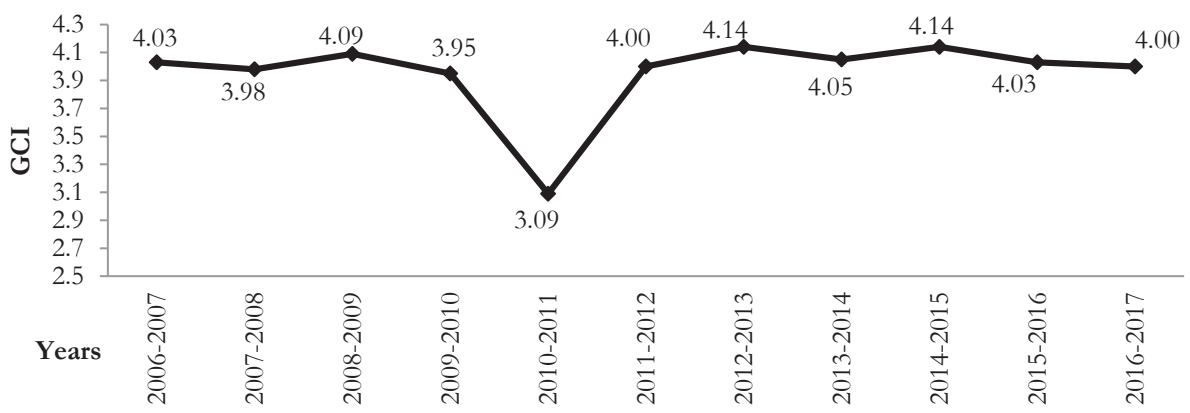

Fig. 1 - Global Competitiveness Index (GCI) for Ukrainian Economy in 2006-2017. Source: bttp://www3.

weforum.org

At the same time, we should admit that GCI is an abstract indicator to a certain extent and illustrates only general idea about the nature of the country's competitiveness. It is not possible to assess trends in economy's development and make forecasts about its short-term and long-term economic growth (Xia et al., 2012) based only on the GCI's score, because it aggregates 114 indicators which have a multidirectional impact.

The key feature of national economic competitiveness is the ability of a country to reach sustainably high growth rates (WEF, 2015). Therefore, one of the major indicators of competitiveness level is GDP per capita, which shows the level of consumption per capita and is strongly correlated with welfare in the country. According to this indicator, Ukraine got 118th rank among 190 countries in 2017 and belongs to the group of poorest countries (WEF, 2017). Figure 2 shows that Ukraine is increasingly moving away not only from developed countries but also from the middle-income countries. 


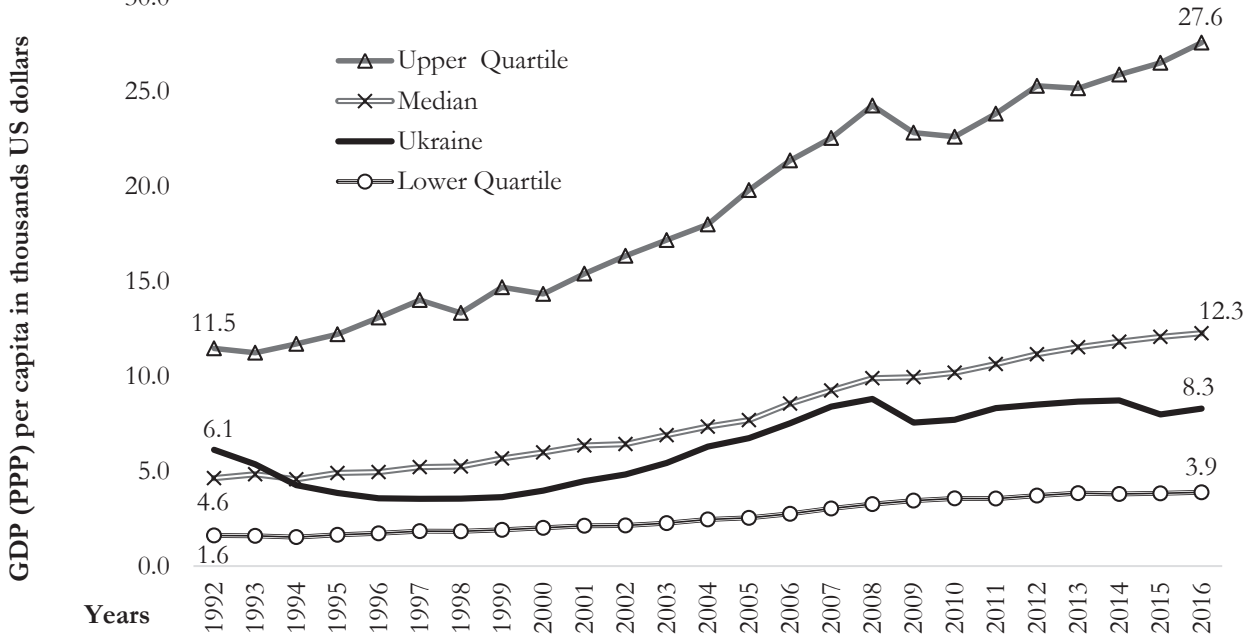

Fig. 2 - Quartiles of GDP (PPP) per capita in the world in 1992-2016 (in thousand US dollars). Source: own calculations based on the data from International Monetary Fund World Economic Outlook

In 1992, relatively sustainable patterns of economic growth of all countries were formed in the world but their growth rates are fundamentally different. $25 \%$ of the poorest countries could increase the value of GDP per capita from $\$ 1,6$ thousand to a maximum level - \$3,9 thousand.

The annual average absolute growth of this indicator was $\$ 96$. At the same time, $25 \%$ of the richest countries were able to reach the average annual growth of almost $\$ 671$. Exceeding by 7 times of growth rates in developed economies shows that the innovation economies are rapidly ahead other countries.

Trends in development of Ukrainian economy have always varied and depended on temporary world conjuncture and factors. In 1999, Ukraine reached gradual economic growth after coping with the collapse crisis of USSR, however, it was not able to fully restore the pre-crisis level of development. Nowadays, Ukraine has extremely low positions according to the GDP growth ratings (Table 1). When at the beginning of its independence Ukraine was in the group of European countries (Poland, Romania, Latvia), these days it is in the group of countries from the Third World (Morocco, Bhutan, Belize).

Tab. 1 - List of countries by GDP (PPP) per capita. Source: IMF (2018)

\begin{tabular}{|l|l|l|l|l|l|}
\hline \multicolumn{2}{|l|}{1992} & \multicolumn{2}{l|}{2016} \\
\hline $\begin{array}{l}\text { Rank in the } \\
\text { world rating }\end{array}$ & Countries & $\begin{array}{l}\text { GDP (PPP) } \\
\text { per capita, in } \\
\text { thousand US } \\
\text { dollars }\end{array}$ & $\begin{array}{l}\text { Rank in } \\
\text { the world } \\
\text { rating }\end{array}$ & Countries & $\begin{array}{l}\text { GDP (PPP) } \\
\text { per capita, in } \\
\text { thousand US } \\
\text { dollars }\end{array}$ \\
\hline
\end{tabular}




\begin{tabular}{|l|l|l|l|l|l|}
\hline 64 & St. Lucia & 6.7 & 113 & Jamaica & 9.0 \\
\hline 65 & Poland & 6.6 & 114 & El Salvador & 8.9 \\
\hline 66 & South Africa & 6.2 & 115 & Libya & 8.7 \\
\hline 67 & Romania & 6.2 & 116 & Armenia & 8.6 \\
\hline 68 & FYR Macedonia & 6.2 & 117 & Morocco & 8.3 \\
\hline 69 & Ukraine & 6.1 & 118 & Ukraine & 8.3 \\
\hline 70 & Suriname & 6.1 & 119 & Bhutan & 8.2 \\
\hline 71 & Latvia & 6.0 & 120 & Belize & 8.2 \\
\hline 72 & Panama & 5.9 & 121 & Guatemala & 7.9 \\
\hline 73 & Costa Rica & 5.8 & 122 & Guyana & 7.9 \\
\hline 74 & Botswana & 5.8 & 123 & Philippines & 7.7 \\
\hline
\end{tabular}

It is also important to emphasize that despite of a certain growth of GDP per capita, ranks of Ukraine in this international ranking of competitiveness were worsening (Figure 3).

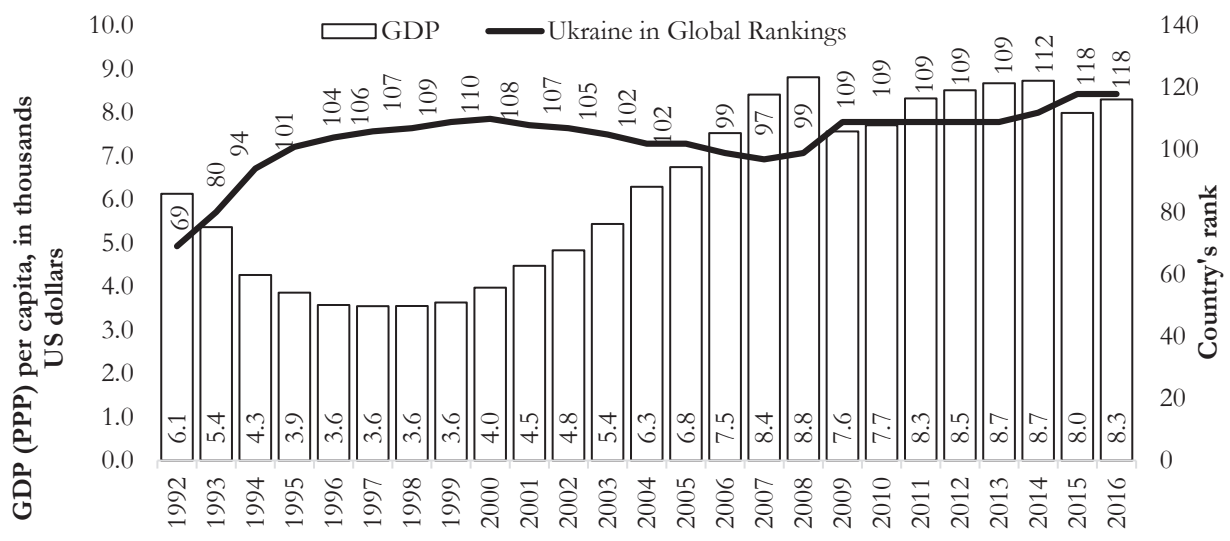

Fig. 3 - Assessments of economic development of Ukraine in 1992-2016. Source: IMF (2018)

First of all, such situation was caused by significantly higher growth rates in other countries. Nowadays, the GDP (PPP) per capita in Ukraine counts only $14,3 \%$ of corresponding US indicator, $11,8 \%$ of Norwegian and $27,4 \%$ of Polish indicator. Even among Post-Soviet countries, Ukraine leaves behind only Moldova, Uzbekistan, Kyrgyz Republic and Tajikistan according to this indicator (Table 2). Almost all Post-Soviet countries were able to successfully overcome consequences of the world 1998 crisis except for Ukraine and Kyrgyz Republic.

Tab. 2 - The dynamics of GDP per capita changes and rank in the international rating of competitiveness in Post-Soviet countries. Source: IMF (2018) 


\begin{tabular}{|l|l|l|l|l|l|l|l|}
\hline \multirow{2}{*}{ No. } & \multirow{2}{*}{\begin{tabular}{l} 
Countries \\
\cline { 3 - 8 }
\end{tabular}} & & \multicolumn{3}{l}{$\begin{array}{l}\text { GDP (PPP) per capita, in thou- } \\
\text { sand US dollars }\end{array}$} & \multicolumn{2}{l}{$\begin{array}{l}\text { Position in the world } \\
\text { rating }\end{array}$} \\
\cline { 3 - 8 } & & 1998 & 2016 & $\begin{array}{l}\text { absolute } \\
\text { change }\end{array}$ & 1998 & 2016 & $\begin{array}{l}\text { change } \\
\text { in rating }\end{array}$ \\
\hline 1 & Lithuania & 8.9 & 30.0 & 21.1 & 64 & 45 & 19 \\
\hline 2 & Estonia & 10.7 & 29.3 & 18.6 & 55 & 46 & 9 \\
\hline 3 & Russian Federaion & 9.1 & 26.5 & 17.4 & 62 & 53 & 9 \\
\hline 4 & Latvia & 7.8 & 25.7 & 17.9 & 69 & 55 & 14 \\
\hline 5 & Kazakhstan & 6.7 & 25.1 & 18.4 & 77 & 57 & 20 \\
\hline 6 & Belarus & 5.3 & 18.0 & 12.7 & 90 & 72 & 18 \\
\hline 7 & Turkmenistan & 1.8 & 17.5 & 15.7 & 134 & 74 & 60 \\
\hline 8 & Azerbaijan & 3.0 & 17.4 & 14.4 & 114 & 75 & 39 \\
\hline 9 & Georgia & 2.3 & 10.0 & 7.7 & 124 & 109 & 15 \\
\hline 10 & Armenia & 2.0 & 8.6 & 6.6 & 131 & 116 & 15 \\
\hline 11 & Ukraine & 3.6 & 8.3 & 4.7 & 107 & 118 & -11 \\
\hline 12 & Uzbekistan & 1.8 & 6.6 & 4.8 & 142 & 129 & 13 \\
\hline 13 & Moldova & 1.8 & 5.3 & 3.5 & 139 & 137 & 2 \\
\hline 14 & Kyrgyz Republic & 1.5 & 3.5 & 2.0 & 147 & 151 & -4 \\
\hline 15 & Tajikistan & 0.9 & 3.0 & 2.2 & 167 & 159 & 8 \\
\hline
\end{tabular}

It is important to emphasize the point that almost in all analyzed countries, the growth rates of GDP (PPP) per capita exceed this indicator in Ukraine.

A decrease in competitiveness negatively affected the position and role of Ukraine in the world economy and also the image of the country. Particularly the share of Ukraine in the gross world product decreased more than 3.3 times since the independence was proclaimed (Figure 4).

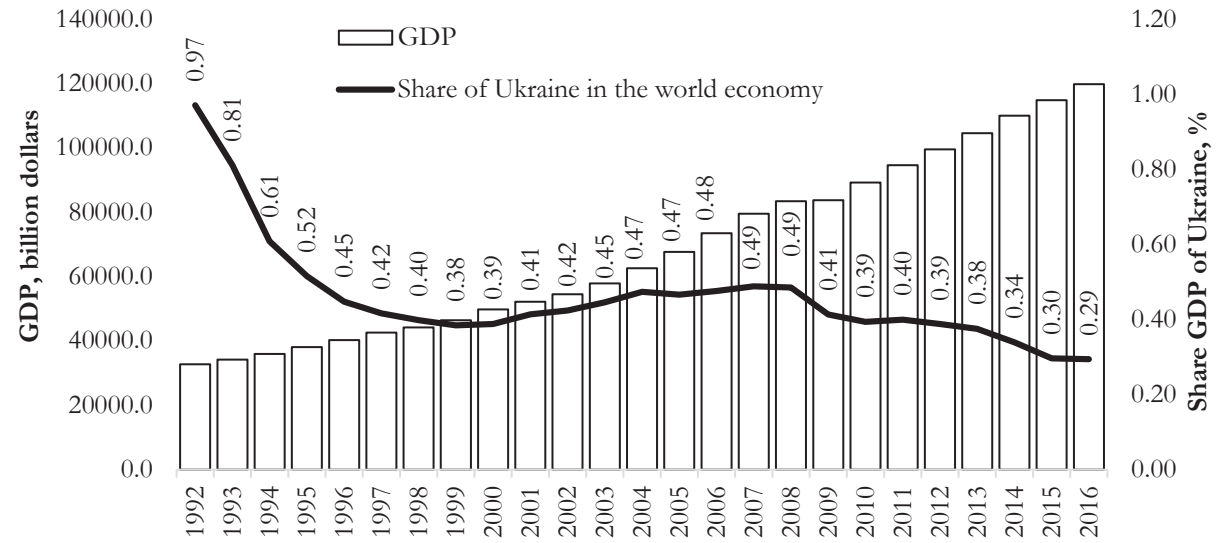

Fig. 4 - The share of Ukraine in the world economy. Source: own calculation based on IMF (2018) 
Therefore, so promising Ukraine at the beginning of 90s of 20th century became an economic outsider. During this time, Ukraine lost one third of its own GDP in physical terms. According to the World Bank forecasts, the annual growth of Ukrainian GDP will count on average only $1 \%$ till 2050. The situation looks critical because even the annual GDP growth rates typical for developed economies at a level of $2-4 \%$ are incapable of significantly changing competitive positions of Ukraine in the world not only in a medium-, but also in a long-term. They will only strengthen a gap between Ukraine and the other world (Figure 5).

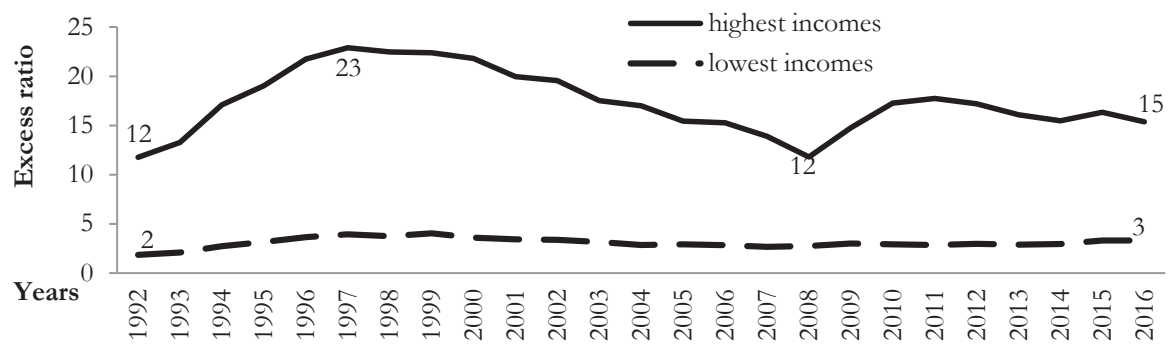

Fig. 5 - The excess ratio of GDP (PPP) per capita of developed economies over Ukraine. Source: own calculation based on IMF (2018)

The existing dynamics of Ukrainian economy growth could not be considered not only as acceptable but even satisfactory. A country having high potential and was capable to join the group of developed countries at the beginning of $90 \mathrm{~s}$, has significantly decreased its competitiveness during last years. We suppose that the main reasons for decreasing Ukrainian economy competitiveness and thus its welfare level are the following:

First, the irrational structure of Ukrainian economy (more than 54\% of output are drawn from the unproductive sectors which do not create added value, more than $12 \%$ - from agriculture and only 33\% - from industry, building and information) (Figure 6).

3.7

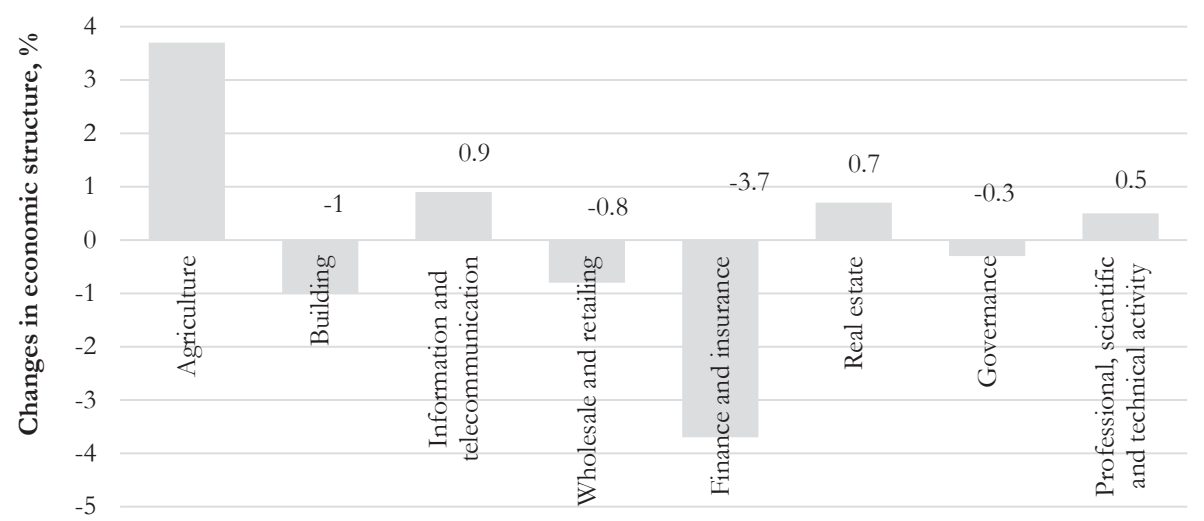

Fig. 6 - The structure of gross added value by types of economic activity. Source: own calculations based on the data from State Statistic Service of Ukraine (2018) 
Second, a low level of technological and innovative development. At the first sight, Ukraine has a range of competitive advantages in innovations according to the results of 2017. Ukraine got 25 th position in rating of the availability of scientists and engineers, 52nd - in PCT patents and 60 th - in quality of scientific research institutions (WEF, 2017). Ukraine has significant scientific and technical potential, famous scientific schools and prominent scientific achievements concentrated in academic, university and industrial areas. At the same time, the indicator of science-intensive of Ukrainian GDP (the share of expenditures for implementation of scientific researches and developments in GDP) decreased almost twice in 2010-2017 and counts 20\% of this average indicator in EU (Figure 7).

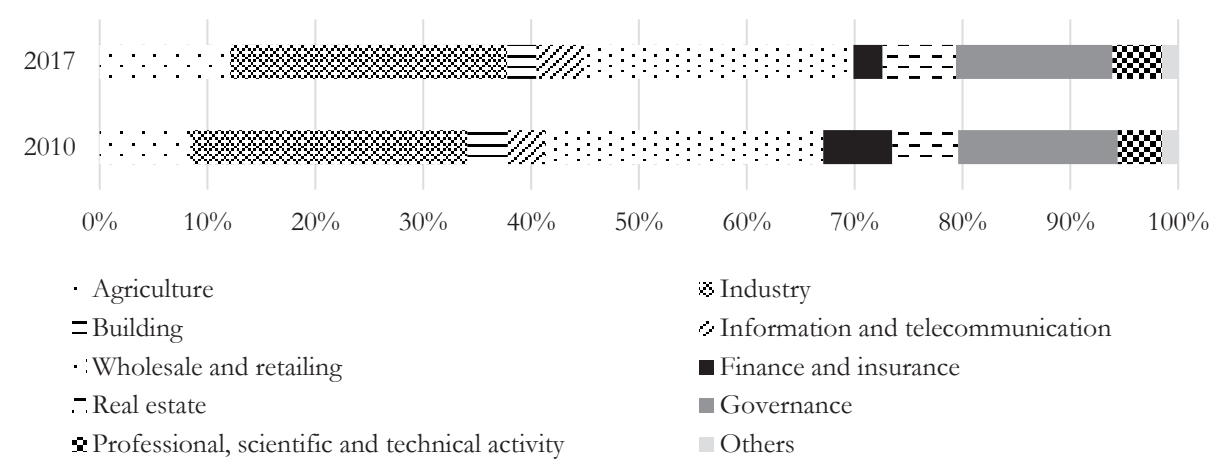

Fig. 7 - The share of expenditures for implementation of scientific researches and developments in Ukraine. Source: State Statistic Service of Ukraine (2018)

Third, the irrational structure of export (more than two thirds of export are raw materials and products with a low processing level and a low added value) and import (products with a high processing level and a high added value). According to the United Nations Commodity Trade Statistics, the share of high-tech goods export from Ukraine in the structure of commodity export was approximately 3\% in 2004-2014 (UN, 2016). Raw materials and products of primary processing still dominate Ukrainian exports, with the incomes from sales depending on the current economic conjuncture with global markets. For this reason, Ukraine had a negative trade balance in 2008-2017 (excluding 2014-2015) (Fig. 8). This led to a decrease in GDP and a deterioration in the trade balance.

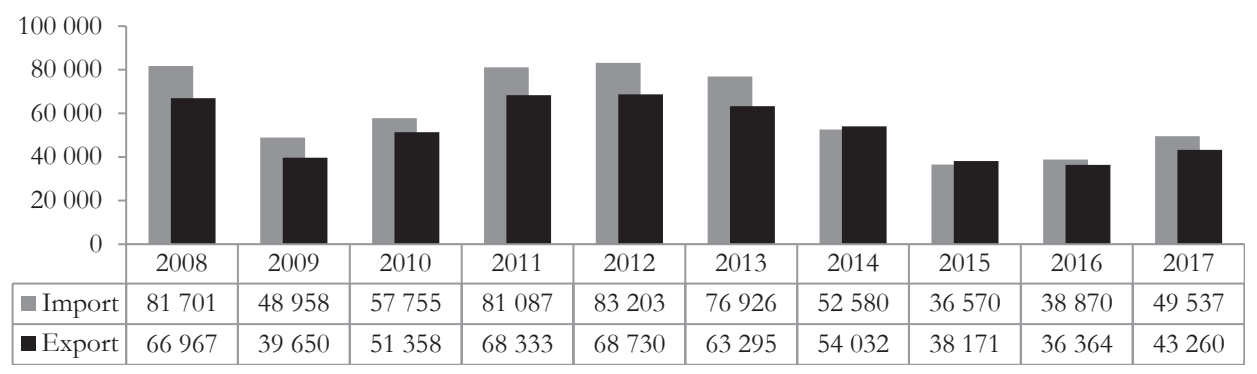

Fig. 8 - External of Ukrainian commodities in 2008-2017, billon US dollars. Source: State Fiscal Service of Ukraine, http://sfs.gov.ua/en/ 
Fourth, a growing gap between human potential and the capacity for self-realization. On the one hand, Ukraine has a lot of talent. According to the Global Human Capital Index 2017 (WEF, 2017), Ukraine was in the 24th position among 130 countries; according to the Global Talent Index 2015, Ukraine was in 42nd place among 60 countries and it is among TOP-10 in this rating in terms of the quality of university education (WEF, 2018). On the other hand, it is complicated to keep talent in the country because of the deficit of opportunities for self-realization in the internal market. Finally, according to the Global Talent Competitiveness Index 2017, Ukraine ranks 61st among 118 countries as a result of talent drain. Moreover, not only researchers but also successful entrepreneurs and talented young people, all of whom could significantly help to develop Ukrainian economy, regularly emigrate from the country (INSEAD, 2018).

Thus, we can conclude that Ukraine will lag behind even other post-Soviet countries in the nearest future if current trends continue and if effective reforms are not implemented. We hope that the beginning of the real economic reform back in 2017 raises the economic position of the country at least back to former levels and thus ensures GDP growth. Therefore, it is urgent to determine the optimal growth rates of Ukrainian economy and to map the period of its recovery. Figure 9 shows that the current stable linear growth trend of the Ukrainian GDP (PPP) per capita growth shows a character of cyclic fluctuations.

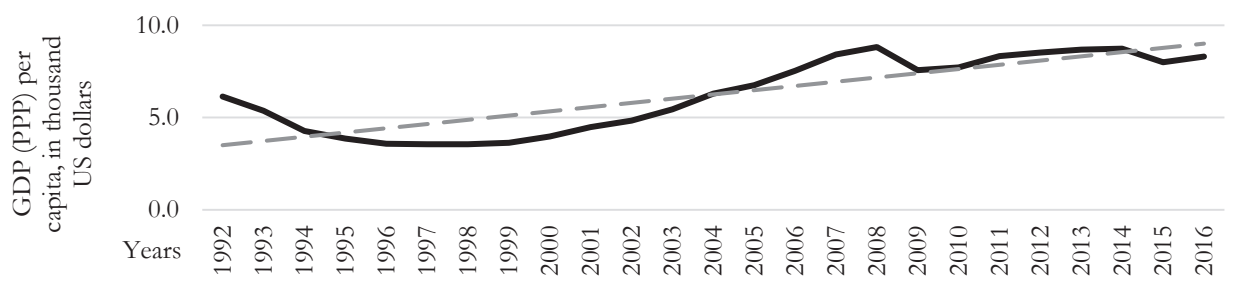

Fig. 9 - Historical and current trends of GDP (PPP) per capita growth in Ukraine. Source: IMF (2018)

Such fluctuations of the trend line are the result of the impact not only of the geopolitical factors, but also of the low competitiveness of Ukrainian goods. The main source of the export growth and thus economic development had been raw materials, which have a certain rhythm in price levels that causes fluctuations of GDP growth rates. This situation has had the worst negative impact, since if we compare Ukraine with the lowest $25 \%$ of the world poorest countries (which also possess raw materials-based economies), we can conclude that the development of these countries is much less dependent on the export of raw materials (Figure 10).

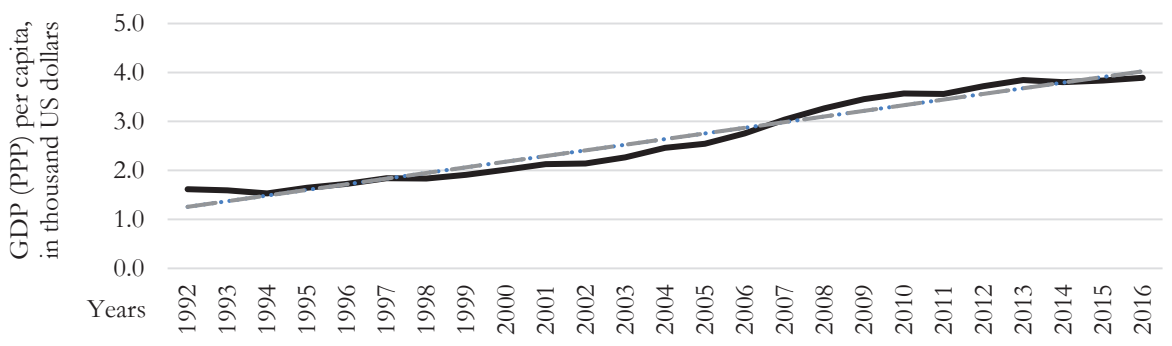

Fig. 10 - The GDP (PPP) dynamics of $25 \%$ of the poorest countries in the world. Source: own calculations 
When we compared the trends of Ukrainian economic growth with the poorest countries in the world, we assessed the impact of time series components. This assessment showed that the impact of the cyclic component as well as random factors on deviation from the stable development trend was $28.5 \%$ in Ukraine, while it was $4.1 \%$ in the poorest countries and $3 \%$ - in the richest countries.

To reestablish lost economic positions or to approach the level of developed countries Ukraine should implement instruments which will help increase economic growth rates (Figure 11).

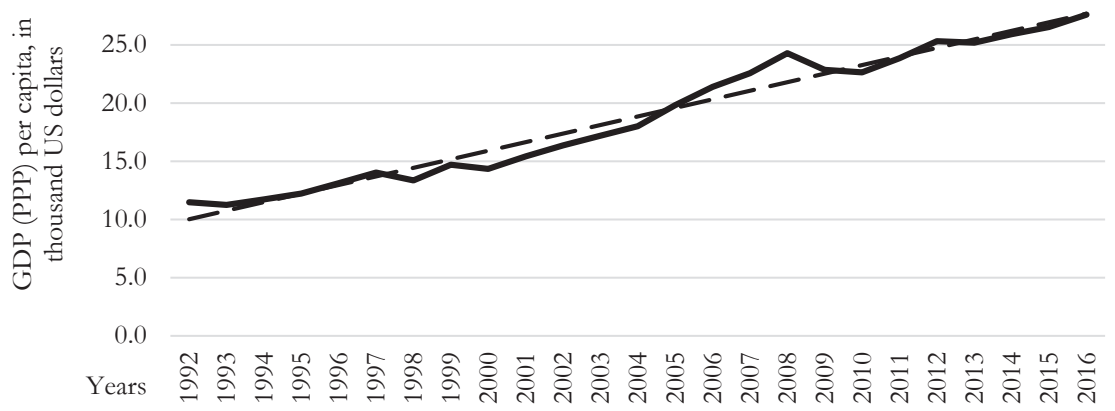

Fig. 11 - Dynamics of GDP (PPP) per capita of the median level for countries worldwide. Source: own calculations

Figure 11 shows that rates and sustainability of growth for $50 \%$ of the economies worldwide (median) significantly exceeds that of Ukraine by almost $45 \%$.

We prepared statistical forecasts to estimate possible ways for the Ukrainian economy to develop. GDP per capita is an indicator with a low level of fluctuation and relatively stable annual absolute growth. For this reason, we have chosen methods of linear extrapolation to prepare the forecast (Figure 12).

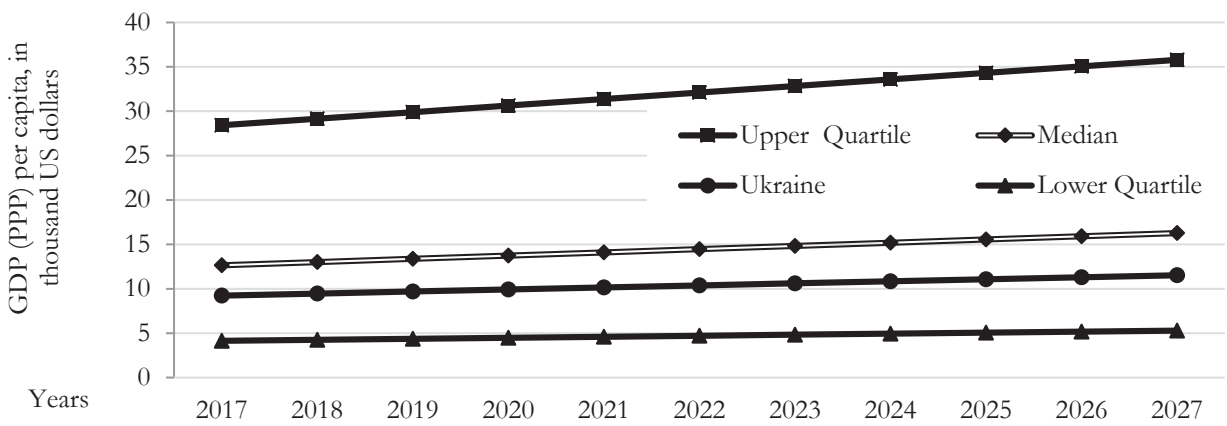

Fig. 12 - The forecast of GDP (PPP) per capita growth. Source: own calculations

Figure 12 shows that steady trends of GDP (PPP) per capita growth will continue during next 10 years (all trend functions have a significance level $-\mathrm{p}$-level $<0.5$ ). We suppose that Ukraine will not be able to reestablish lost positions even in a period significantly longer than forecasted if a range of factors do not change which determine the dynamics of the national economy's growth. Ukraine must have an annual acceleration of GDP (PPP) per capita growth of almost 4- 
5\% to reestablish its 1992 rate of economic development (the highest level since the Soviet Union dissolution). If this takes place, the country would be able to reestablish this rate by 2028-2032 (Figure 13).

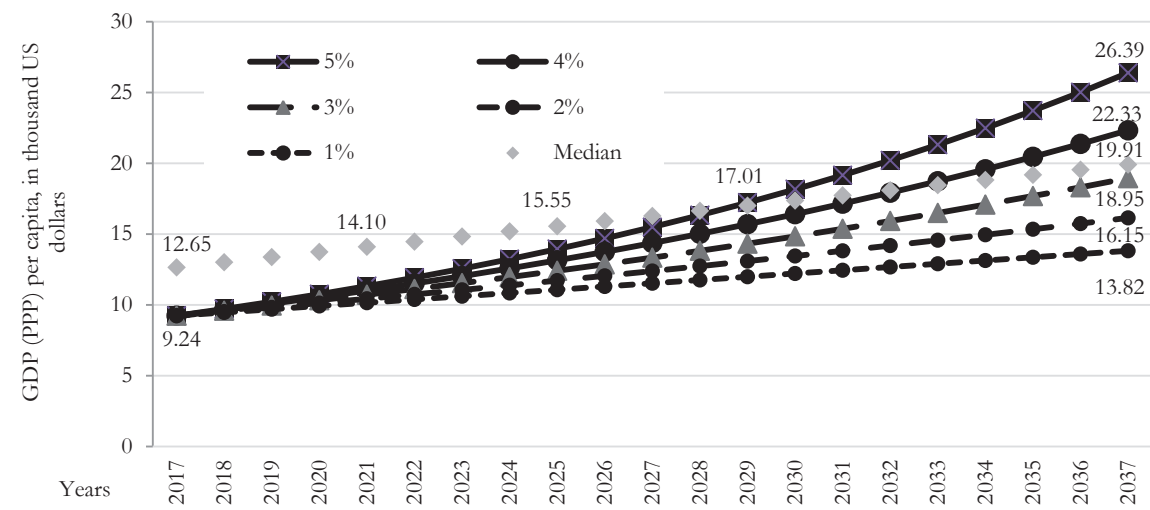

Fig. 13 - Model curves with different growth rates of GDP (PPP) per capita compared to worldwide median growth rates. Source: own calculations

The lack of prospects under the current economic strategy makes necessary a formulation of growth rates for Ukrainian economy (Fig. 14). It will be a very difficult task to catch up with developed economies.

Therefore, Ukraine and other countries with 8000-9000 USD GDP (PPP) per capita have to ensure a relative annual acceleration growth rate of more than $8 \%$ if they want to achieve the level of economic development as can be found in developed economies.

We prepared a statistical forecast of the GDP (PPP) growth under a steady trend that has emerged in East European countries (all forecasts are statistically significant, the level of significance for all forecasts is $\mathrm{p}<0.05)$.

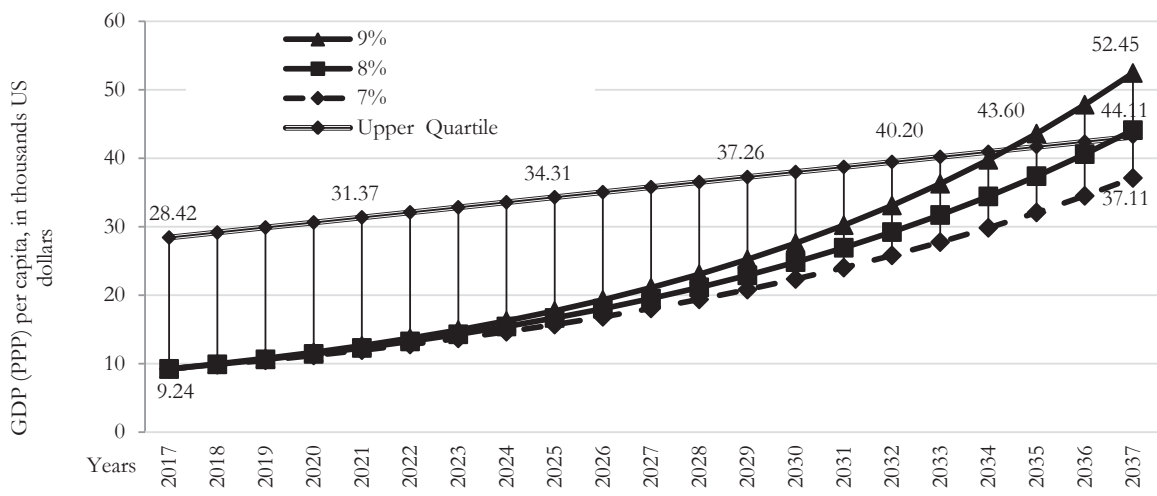

Fig. 14 - Model curves with different growth rates of GDP (PPP) per capita compared to $25 \%$ of the richest economies in the world. Source: own calculations 
Figure 15 shows that the effect of implementation of progressive reforms would allow Ukraine to approach the rate in developed countries by 2034, but the country will remain an outsider in comparison to neighboring Eastern European countries. Ukraine will have a relatively inferior position even under conditions of additional economic growth (8.3 thousand US dollars).

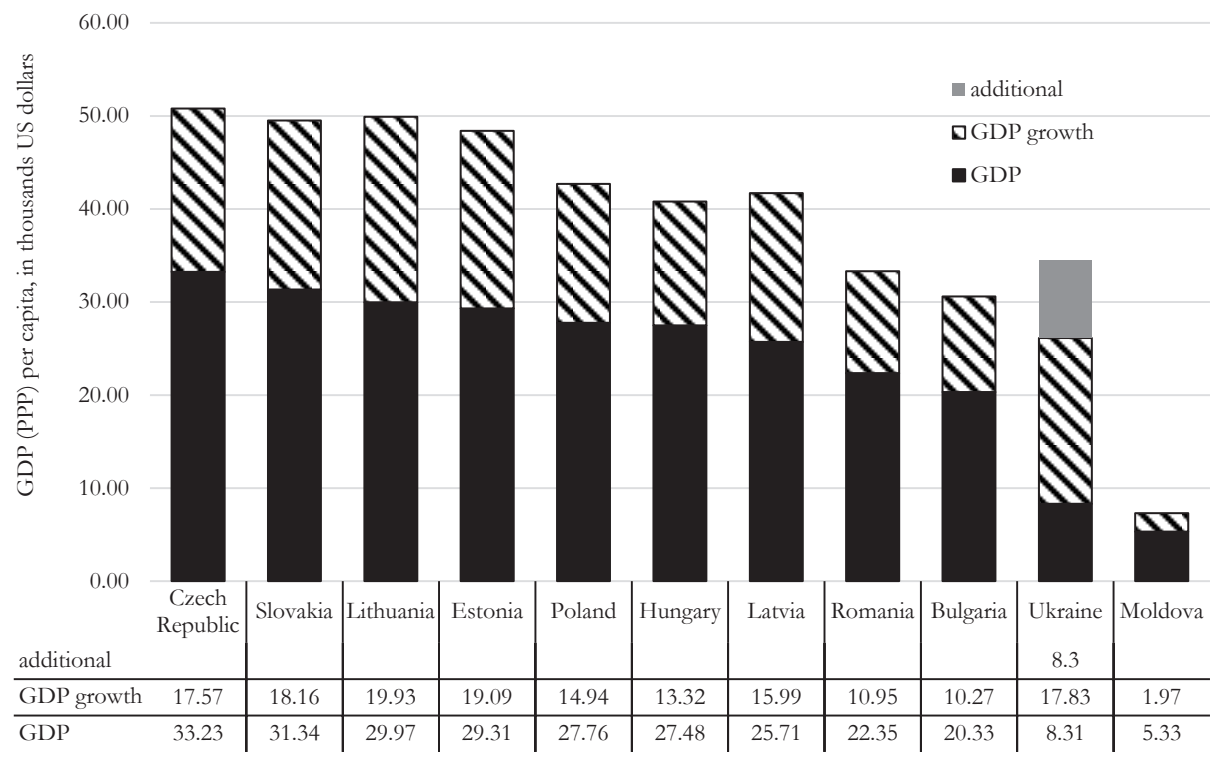

Fig. 15 - The forecast of growth of GDP (PPP) for Eastern European countries in 2034. Source: own calculations

\section{CONCLUSION}

The present authors seek to evaluate whether the aim of the paper was fulfilled and presents the main findings that countries enter into strong competition to gain global and regional leadership. Usually the stronger actors win in such tough, intense and dynamic competitive struggle and then form a global core. At the same time, economically and technologically weaker countries participating as consumers in the technological chain do not strive for the development of a real sector of the economy by using innovations, and do not devote much attention to the development of science and education, and thus worsen their competitiveness. Unfortunately, Ukraine also ranks among such countries.

A decrease in competitiveness and the worsening of living standards are interdependent factors. Ukraine was able to generate annual GDP growth rates on average $\$ 92$ per capita during the last 24 years, which is less than in developing countries (\$98) and significantly less than in other developed economies. A backlog of $25 \%$ in developed economies is very significant: in 2016, revenues of Ukraine were 3 times lower than the lowest revenues of developed economies and 15 times lower than revenues in the richest countries of the world. 
This is the reason Ukraine faces the difficult task of using all its potential opportunities to accelerate economic growth. To address this issue, it is necessary to make several important steps:

1. to establish a real (not formal) program of increasing Ukrainian economic competitiveness based on measures to reestablish industry and to develop the service sector

2. to change from the raw materials-based model of economic development to the innovationoriented model

3. to reestablish high-tech industries and to develop new ones based on forming a powerful innovative, scientific and technical potential

4. to improve quality of the business environment, to enhance 'game rules' and to develop entrepreneurship culture

5. to make a gradual transition towards a policy of neo-protectionism

6. to become oriented towards the prior development of a solvent internal market

7. to develop digital and IT-technologies

8. to develop service industries, especially intellectual-intensive ones

9. to transform social capital into the main production resource along with knowledge and information into the dominant form of ownership and wealth

10.to establish favorable conditions for the retention of 'brains'

Only a high level of Ukrainian economic competitiveness both in internal and international markets could become a reliable basis for increasing the living standards of the population in Ukraine.

\section{References}

1. Bhawsar P., \& Chattopadhyay U. (2015) Competitiveness: Review, Reflections and Directions. Global Business Review, 16 (4), 665-679. https://doi.org/10.1177/09721509155811 15

2. Botrić V., \& Broz T. (2016) Competitiveness, Trade with the EU and Labour Markets: Challenges for the Western Balkans. South East European Journal of Economics and Business, 11 (2), 20-32. https://doi.org/10.1515/jeb-2016-0008

3. Bris, A. (2014). IMD World Competitiveness Center, IMD World Competitiveness Center, Lausanne. Retrieved October 19, 2018 from: https://www.imd.org/wcc/worldcompetitiveness-center/

4. Dobrovic, J., Gallo, P., Mihalcova, B., Stofova, L., \& Szaryszova, P. (2018). Competitiveness Measurement in Terms of the Europe 2020 Strategy. Journal of Competitiveness, 10 (4), 21-37. https://doi.org/10.7441/joc.2018.04.02

5. Flanagan, R., Lu, W., Shen, L., \& Jewell, C. (2007). Competitiveness in Construction: A Critical Review of Research. Construction Management and Economics, 25, 989-1000. https:// doi.org/10.1080/01446190701258039 
6. IMF (2018). Report for Selected Countries and Subjects, International Monetary Fund, Washington D.C.. Retrieved June 11, 2018 from: http://www.imf.org/

7. INSEAD (2018). The Global Talent Competitiveness Index 2018, Fontainebleau, France.

8. Lall, S. (2001). Competitiveness indices and developing countries: an economic evaluation of the global competitiveness report. World Development, 29 (9), 1501-1525. https://doi. org/10.1016/S0305-750X(01)00051-1

9. Olczyk, M. (2016). A Systematic Retrieval of International Competitiveness Literature: A Bibliometric Study. Eurasian Economic Review, 6 (3), 429-457. https://doi.org/10.1007/ s40822-016-0054-9

10. Porter, M. (1993). International competition, International Relations. Moscow: International Relations (Russian language).

11. Reinert, E.S. (2007). How Rich Countries Got Rich and Why Poor Countries Stay Poor, Constable.

12. Sachs, J.D. \& Larrain, F.B. (1993). Macroeconomics in the Global Economy. Englewood: Prentice Hall.

13. Sachs, J. (2000). Globalization and Patterns of Economic Development. Review of World Economics (Weltwirtschaftliches Archiv), 136 (4), 579-600.

14. Simionescu, M. (2016). Competitiveness and Economic Growth in Romanian Regions. Journal of Competitiveness, 8 (4), 46-60, https://doi.org/10.7441/joc.2016.04.03

15. Spence, A. M., \& Hazard, H. A. (Eds.). (1988). International competitiveness. Cambridge: Ballinger Pub Co.

16. Srivastava, D., Shah, H., \& Talha, M. (2006). Determinants of competitiveness in Indian public sector companies: An empirical study. Competitiveness Review, 16 (3/4), 212-222. https://doi.org/10.1108/10595420610818839

17. State Fiscal Service of Ukraine (2018). Customs statistics on commodities foreign trade, State Fiscal Service of Ukraine, Kyiv. Retrieved June 10, 2018 from: http://sfs.gov.ua/ mytna_statystyka/richni_pokaznyky/305879.html

18. State Statistic Service of Ukraine (2018). Scientific Researches and Developments in 2017. Express Review, State Statistic Service of Ukraine, Kyiv. Retrieved June 10, 2018 from: http://www.ukrstat.gov.ua/express/expr2018/05/73.pdf

19. UN (2016). United Nations Commodity Trade Statistics Database, United Nations, Geneva. Retrieved July 15, 2018 from: https://comtrade.un.org/db/ dqQuickQuery.aspx

20. World Economic Forum (2015). Methodology: The 12 Pillars of Competitiveness, World Economic Forum, Geneva. Retrieved September 26, 2017 from: http://reports.weforum. org/ global-competitiveness-report-2014-2015/ methodology/

21. World Economic Forum (2017). The Global Human Capital Report 2017, World Economic Forum, Geneva. Retrieved June 21, 2018 from: http://www3.weforum.org/docs/WEF_ Global_Human_Capital_Report_2017.pdf

22. World Economic Forum (2017). The Global Competitiveness Report 2017-2018, World Economic Forum, Geneva. Retrieved March 17, 2018 from: http://www3.weforum. 
org/docs/GCR2017-2018/05FullReport/TheGlobal CompetitivenessReport2017\%E2\% 80\%932018.pdf

23. Xia, R., Liang, T., Zhang, Y., \& Wu, S. (2012). Is global competitive index a good standard to measure economic growth? A suggestion for improvement. International Journal of Services and Standards, 8 (1), 45-57. https://doi.org/10.1504/IJSS.2012.048438

\section{Contact information}

prof. Halyna Fyliuk, Doctor of Economics

Taras Shevchenko National University of Kyiv

Faculty of Economics

Department of Business Economics

Ukraine

E-mail:gfiluk@ukr.net

ORCID: 0000-0002-8030-5757

assoc. prof. Ihor Honchar, Ph.D.

Taras Shevchenko National University of Kyiv

Faculty of Economics

Department of Statistics and Demography

Ukraine

E-mail:i-gonchar@ukr.net

ORCID:0000-0002-3167-1240

asst. prof. Vasylyna Kolosha, Ph.D.

Taras Shevchenko National University of Kyiv

Faculty of Economics

Department of Economic Theory, Macro- and Microeconomics

Ukraine

E-mail:fvasilina@gmail.com

ORCID:0000-0001-6270-8416 